\title{
THE 'HANDMAID' AND THE 'CHAMBERMAID': A COMPARATIVE ANALYSIS OF ATWOOD’S SEMINAL NOVEL FROM A FEMINIST PERSPECTIVE
}

\author{
Alexandra-Maria VRÎNCEANU \\ Alexandru Ioan Cuza University of Iași, Romania
}

\begin{abstract}
This article is an analysis from a feminist perspective of the two Romanian translations of Margaret Atwood's The Handmaid's Tale. By adopting Antoine Berman's three pronged model of translation criticism, I attempt to identify several differences between the translations. Therefore, it will prove pertinent to see whether the translators adhere to the author's style, are faithful to the tone, imagery, wordplay and ludic nature of the text, if they prefer to steer clear of more adventurous translation strategies and opt for a source-oriented translation, keeping to the initial structure and employing mostly syntactic strategies. Another important element that surfaces and plays a paramount role is that of the translator's visibility, more precisely those instances wherein she makes her voice known, be it through an explanatory footnote or, perhaps, a translator's gloss at the end of the translated text. The translators' own backgrounds are relevant in the case at hand as well, as their experience and formation influence their preferences for a certain style and translation strategies.
\end{abstract}

Keywords: visibility, voice, translation criticism, wordplay, ideology, faithfulness, footnotes, gloss

\section{INTRODUCTION}

This article offers a piece of translation criticism performed with the use of translation scholar Antoine Berman's method of translation analysis. With respect to the methodological framework of the investigation, focus is drawn to the author's background, as well as to locating the work in its context (zeitgeist). Having chosen the novel The Handmaid's Tale by Canadian author Margaret

LiNGUACULTURE vol. 12, no. 2, 2021

Published: 31 December 2021

DOI: 10.4773/lincu-2021-2-0206

ISSN (print): 2067-9696 || ISSN (online): 2285-9403 || www.journal.linguaculture.ro 
Atwood and its translations into Romanian, I will be attempting to ascertain whether the translators adhere both to the ideology and to the experimental style, assess how certain relevant excerpts were translated, as well as identify some particular challenges the translation poses (Boase-Beier in Boase-Beier et al. 22). Throughout my analyses, I will also use the classification of translation strategies provided by Andrew Chesterman in the 2016 edition of his book Memes of Translation. This classification of translation strategies will help my analyses, in that it will provide some benchmarks according to which I will comment and compare the translators' solutions and preferred strategies.

Herein I will focus on an analysis, from a feminist perspective, of Margaret Atwood's The Handmaid's Tale, and its two Romanian translations by two female translators for three separate publishing houses, namely Monica Bottez (for Univers, Galaad 2195 in 1995, then for Leda Publishing House, Povestea cameristei, in 2006), and Diana Marin-Caea (for Paladin in 2017, Povestea slujitoarei). The striking translation choice that immediately sets the versions apart, without so much as cracking open the books and peeking inside is glaringly obvious, and can be found in the translated title: Galaad 2195 (The Handmaid's Tale), Povestea slujitoarei and Povestea cameristei. Firstly, the 1995 version of the title clearly wished to cater to the taste of science fiction aficionados (the Collection is called "Sci-Fi Novels" and is featured on the front cover). The first part of the initial title Bottez came up with makes sense, as Offred's story is later revealed to be the center of discussions at a conference taking part in the distant future, in 2195, more precisely. One interpretation for the fact that she left the title of the source text untranslated between brackets might suggest that, while the editors may have wanted the novel presented as science fiction material exclusively, she perhaps wanted the (niche) audience familiar with Atwood's work, or feminist writings in general, to be aware of the profound implications present in the title, by means of the interplay between 'tale' as a story and 'tail', as in the derogatory expression 'piece of tail', objectifying women and perceiving them merely as sexual playthings, as she mentions later on in the gloss at the end (page 290 in the Univers edition). Therefore, it is safe to state that it was not an omission on the translator's part, rather, it was the end result of the influence exerted by a series of factors, more or less pragmatic in nature. With respect to the 2006 version of Bottez' title, as compared to the 2017 title, suffice it to say that, in the target language, 'cameristă' (the equivalent of 'chambermaid') either refers to the woman in service of a lady or to a woman employed in an establishment such as a hotel or a motel, in charge of cleaning the rooms, whereas 'slujitoare' also carries this symbolic meaning, referring to the service handmaids perform for Gilead and its leaders. Going straight to the source the author drew inspiration for the idea of 
'handmaids', namely Genesis 30:1-3, the story of Rachel and Jacob: “And she said, Behold my maid Bilhah, go in unto her; and she shall bear upon my knees, that I may also have children by her", the 1988 Romanian version (reproducing the 1982 text) features the word 'roaba' ("Iată roaba mea Bilha; intră la ea și ea va naște pe genunchii mei și voi avea și eu copii printr-însa”) [42], carrying the meaning of 'slave', of a woman 'in service' of others. With 'slujitoare', there is also the implication of subordination, of service, this being, in the words of feminist writer and professor Mihaela Miroiu, "[...] the common experience of women and other categories deemed to be lesser" [My translation, based on her article which appeared in the Romanian journal Secolul 20 (The 20th Century), in 1996].

\section{MARGARET ATWOOD: A MASTER CREATOR OF GRIM DYSTOPIAN FUTURES}

Canadian poet and novelist Margaret Atwood was born in Ottawa in 1939 and 'became a poet' at age 16, never looking back. For a mere idea of just how influential this acclaimed writer who refuses to declare herself a feminist is, it is worth mentioning that her works have been translated into more than 22 languages. Even though she has repeatedly refused to be interlinked with feminist discourse, the themes, imagery and symbolism in her novels show sympathy for the cause. On more than one occasion has she emphasized the fact that: "I don't consider it feminism; I just consider it social realism." (qtd. in Kaminski "Preserving Mythologies" 27 in Tolan 2). Her writing is characterized by focusing primarily on women themselves, on bringing them to the forefront, putting the spotlight on female bodies; in her own words: "As for woman, capital W, we got stuck with that for centuries. Eternal woman. But really, 'Woman' is the sum total of women. It doesn't exist apart from that, except as an abstracted idea." (Macpherson 22-23). In spite of Atwood's refusal to openly align herself with the feminist movement, as Fiona Tolan states in her work Margaret Atwood Feminism and Fiction, "such denials do not preclude a feminist examination of her writing. Because feminism is not a bounded, monolithic theory, it is insupportable to claim that a novel may react and interact with feminist themes and still operate outside of feminism.” [2] Many have tried to make sense and make a distinction between Atwood seen as Author and as Reader, to find out what has influenced her in tackling the themes and constructing her characters. Tolan, for instance, claims that

The lens through which Atwood is viewing the society that appears in her books is the lens of her own experience, and as such is unique, and consequently the picture that it produces is equally unique. Thus the author's 
perception of society is inevitably a transformative one, generating new images, new associations, and new ideas. (Tolan 8)

Apart from themes such as origins and identity, 'the imprisoning gaze', articulating one's body or 'narrating the self' (Tolan), women's bodies are a prevalent focus in Atwood's novels, with her protagonists showing "marked signs of bodily unease": socio-political anorexia, shape-shifting, difficulty coming to terms with her ageing body (Davies 58). As such, some of her characters are aware of their bodies and their inherent power, with a telling example here being The Handmaid's Tale's Offred suddenly realizing “[...] I enjoy the power; power of a dog bone, passive but there" (Atwood 24). The body thus becomes "[...] the site on which political power is exercised and the site on which abuse is practiced and in turn rehearsed" (Davies 58). Later on, however, Offred's mind is so consumed by the indoctrination (possibly also by the fear of the regime), that she cringes at the sight of her own naked body:

"My nakedness is strange to me already. My body seems outdated. Did I really wear bathing suits, at the beach? I did, without thought, among men, without caring that my legs, my arms, my thighs and back were on display, could be seen. Shameful, immodest. I avoid looking down at my body, not so much because it's shameful or immodest but because I don't want to see it. I don't want to look at something that determines me so completely." (Atwood 55)

\section{ANALYSIS AND CONFRONTATION OF THE TWO ROMANIAN VERSIONS: POVESTEA CAMERISTEI (2006) AND POVESTEA SLUJITOAREI (2017)}

Prior to the actual analysis, I will make some preliminary textual considerations, pointing out several characteristic features of Atwood's style, together with an interpretation of the novel itself, highlighting some important excerpts. Another fact worthwhile mentioning is that I have chosen to focus only on the Leda version of Bottez' translation, as there is virtually no difference between the two texts content-wise, except for the translation of the title, which has already been discussed.

After its publication in 1985, The Handmaid's Tale gained popularity and prestigious awards and as such, it was later (1990) made into a film which did not receive the same warmth from wide audiences. Some critics have commented upon this aspect, positing that Hollywood sought a heroine with gumption and was deterred by Offred's "necessary passivity” (Macpherson 56). On The Handmaid's Tale, Atwood stated that "[...] when I wrote it I was making 
sure I wasn't putting anything into it that humans had not already done somewhere at some time." (Devaul 20) The novel depicts a grim dystopian future, where America as we know it today has become Gilead, a Christian theocratic republic, wherein 'handmaids', women ripped from their day-to-day lives, are forced to become surrogates for privileged couples who cannot bear children of their own. Here, women are the sad result of a totalitarian, patriarchal society (not unlike Romania prior to 1989), which leaves them with an exacerbated ethical sense of duty to the point of self-effacement (Miroiu "Experientele femeilor" 30); their behavior comes only as testament to the fact that they are but things to use (to bear children) as long as they are fertile and obedient, then dispose of once their usefulness has run its course. What follows is the plight of 'Offred', as told in her own words ("I would like to believe this is a story I'm telling. [...] If it's a story I'm telling, then I have control over the ending.”) (Atwood 37). It is quite clear that the author intends to make us aware of the fact that the novel takes place in a not-so-distant future, as contemporary society's dependence on storage and sharing of personal information, various scientific interventions, genetic modifications, lack of awareness with respect to how we treat and care for the environment, is leading us ever closer to that point of no return (Macpherson 53). Gillead places strict roles to each and every woman (as evidenced by their clothing - red for Handmaids, gray for Marthas, blue for Wives, etc.). The style in which the novel is written is a mix of presentday and flashbacks, as the reader finds out that Offred's real name is June, raised by a single mother who was also an advocate for women's rights, that after the fall of the former US Government, she lost her job (women could not hold jobs or even have their own money and bank accounts) and she and her husband Luke, together with their daughter, tried to flee into Canada, in search of a better life. Having been caught and turned into a 'Handmaid', she is in service to the Commander and his wife, Serena Joy. A spiral of events unfolds: a secret resistance, an affair with Nick, the Commander's Guardian, an illicit liaison with Fred Waterford, the Commander himself, all of which culminate with Offred being caught and taken away by Eyes (possibly members of the Resistance). In the end, the story is revealed to have been part of a symposium on Gileadean Studies in 2195, with the implication being that there was hope after Gilead (Bauer).

With respect to the novel and the story, this is the realm of 'speculative fiction', characterized by 'reality-bending'; this genre "[...] provides the ideal landscape for discussions of alterity, oppression, and hegemony, especially along the axes of gender and race" (Matthews 2). Another aspect of note is the fact that the novel focuses on the antithesis between past 'free' female subjectivity and 'enslaved' subjectivity in the present, the Handmaids' harsh reality (8). In what can be construed as a self-protection mechanism (for 
breaches can result in being sent to the Colonies, to live with the Unwomen, or hanging on the Wall), Offred constantly reminds herself of Aunt Lydia's teachings; sometimes she is even aware of the indoctrination she has been subjected to: "We are fascinated, but also repelled. [...] It has taken so little time to change our minds, about things like this." (Atwood 29). The past is still there, at the back of her mind, but she is forced to think and act in a different paradigm, "to rectify two conflicting modes of existence - the truth of lived experience, and the artificiality of socially constructed narratives.” (Matthews 9). However, it must be said that the protagonist is not a heroine, she is not the feisty hero some readers may expect or be used to. Rather, she is "a passive everywoman", waiting to be rescued (Macpherson 56) and taking some comfort in her ignorance: "We lived, as usual, by ignoring. Ignoring isn't the same as ignorance, you have to work at it." (Atwood 50). To this ignorance I feel compelled to add another adjective: 'resignation'. As theorist Mihaela Miroiu stated, "[...] often subordination and obedience become vices (misdemeanour stemming from obedience)" ("Experiențele femeilor" 30, my translation from the Romanian). I believe this especially rings true in Offred's case, as women are the ones with the power to break free of humiliating and demeaning circumstances, but this is simply not possible outside a "feminist self-awareness" (Miroiu 30). In Offred's defense, this is what Atwood wants the reader to understand, this is the tragedy of a system like Gilead; no wonder, then, that these women have lost their will to fight, because this is precisely what it was designed to do: gradually drain them of any grit. As the members of Mayday, the resistance group fighting against the regime, as well as the previous handmaid who rested her head on what was to become Offred's pillow - carved onto the closet floor, "[...] in the corner where the darkest shadow fell: "Nolite te bastardes carborundorum”” (Atwood 47), or "Don't let the bastards grind you down”.

In Romania, the first translator of the novel was Monica Bottez, a professor at the University of Bucharest. Her translation was first published in 1995, at Univers Publishing house, under the title Galaad 2195. Eleven years later (2006), the same translated text came out with Leda Publishing House with a significant change of title - Povestea cameristei. Since, generally, contracts between translators and publishing houses lay down that the Publishing House owns the exclusive rights to the book for a period ranging between 3-7 years (the transfer of rights), and that the Publishing House may also transfer the rights to other parties by means of an addendum, it can be assumed that this is what happened in the case at hand: Univers sold/transferred the rights to the Corint Editorial Group which owns Leda, and so the translation was republished after the period elapsed (perhaps a new contract was entered into between the 
translator and the new publishing house, with a half payment for the same target text). It is paramount to mention right at the beginning of the analysis an aspect which immediately sets the two translators apart, namely the criterion of 'experience', more precisely with respect to Canadianism and feminism and also to Atwood's works. As such, professor Bottez' formation as one of the leading Canadianists in the country, as well as her many articles and publications on, for instance, "Canadian Fiction in English”, “A Postmodernist Version of Canadian Identity", "Margaret Laurence's The Diviners: A Paradigmatic Canadian Novel” among others, are testament to her sensitivity and connection to Canadian literature and to Atwood's themes, style, tone and imagery.

Later on, with the premiere of the American TV series based on the novel on Hulu, in 2017, Romanian audiences had a newfound interest for Atwood-produced content, and so Paladin Publishing House commissioned Diana Marin-Caea to do another translation, so as to meet the expectations of a new generation of readers. The new translation was entitled Povestea slujitoarei and it was published in 2017. The attempt to entice readers and fans of the show is apparent in the extra-textual elements, starting with the mention 'The book upon which the phenomenon TV series is based.', as well as the picture printed on the cover of the Paladin version, which came out only a few months after the series premiered: it is a promotional poster of the main actress portraying Offred, looking defiantly and cunningly at you from the cover, with the now famous ruby-red robes and white wings, an armed Guardian behind her and smears of blood on the wall. Similarly, over a decade before, the Univers edition had engaged the readers of the late " 90 s by drawing on their interest in all things scifi: besides the aforementioned title of the collection, "Sci-Fi Novels", there were visual elements as well, notably futuristic imagery.

In the following paragraphs, I will be looking at Professor Monica Bottez' 2006 Povestea cameristei and Diana Marin-Caea's 2017 Povestea slujitoarei in tandem, applying Berman's model of translation analysis, and resorting to Chesterman's classification of strategies in order to identify the preferences and procedures at play, analyzing some revealing excerpts, looking at certain defining features of the source text, then ending with the search of the translator, attempting to gain as much insight into her translational position, the translating project and into her translating horizon as possible.

Firstly, reading and rereading the translations, as far as the observance of the norms of the target language (Romanian) goes, they read well, bearing in mind that the 1995 version (and, implicitly, the 2006 one) does showcase Bottez' prowess both as a translator, as well as her intimate knowledge of Canadian literature and of Atwood's style, tone and themes. As a side mention, in the Paladin translation, it appears that the translator has attempted to render some parts in such a way that they feel more 'in tune' with readers nowadays. 
Therefore, the language used feels more familiar and "contemporary" to younger generations, who are more than likely either fans of the TV series, or at the very least familiar with it. Moreover, after reading the respective translations and performing translation criticism, it is apparent that one is more source-oriented (Marin-Caea), whereas the other is more target-oriented (Bottez).

The author's satiric tone and sharp wit also prevail, starting from the very first page, with the mottos she uses, notably Swift's Modest Proposal. As Monica Bottez stresses in her Endnotes (page 292 in the Univers version), it is also worth noting that, as opposed to Swift, Atwood makes no proposal, rather she points out the possible consequences that may arise from certain ideological conflicts typical of the end of the $20^{\text {th }}$ century. Without explicitly condemning the right-wing ideology that goes against feminist tenets - rape, assault or pornography -, the author actually takes a stand against such solutions, which bulldoze any semblance of free will, rights or voice.

Upon confronting the two versions against the source text, several differences are apparent in the following excerpts, which serve to showcase Bottez' propensity toward a more literary and formal language, as evidenced by her formation as a professor, Canadian studies scholar and Atwood aficionado:

ST: There was old sex in the room and loneliness, and expectation, of something without a shape or name. I remember that yearning, for something that was always about to happen and was never the same as the hands that were on us there and then, in the small of the back, or out back, in the parking lot, or in the television room with the sound turned down and only the pictures flickering over lifting flesh. (Atwood 1)

TT 1 (Bottez): În încăpere se simțeau pofte carnale satisfăcute demult, dar şi singurătate sau o assteptare lipsită de un obiect precis, greu de definit. Îmi amintesc acel dor, cum tânjeam după ceva ce părea mereu că e pe punctul de a se întâmpla, ceva total diferit de brațele ce ne încolăceau talia si ne pipăiau în sala de dans, sau în parcare sau în camera TV unde sonorul era închis şi doar imaginile aruncau o lumină şovăielnică asupra cărnii dezlănţuite. (7-8)

TT2 (Marin-Caea): Camera emana miros rânced de sex și singurătate, $\underline{0}$ așteptare a ceva fără formă sau nume. Îmi amintesc că tânjeam după un lucru care era mereu pe punctul de a se întâmpla și care n-avea nimic de-a face cu mâinile așezate atunci, în acel loc, pe spatele nostru, deasupra soldurilor, sau în spate, în parcare, ori în camera cu televizorul, cu sonorul dat încet și imaginile ecranului luminându-ne carnea frământată. (9) [all emphases mine] 
Thus, Marin-Caea's version follows a more literal route, keeping the ST structure and making changes at a formal level, whereas Bottez resorts to the grammatical strategy of unit shift more often than not (old sex sex-pofte carnale satisfăcute demult). Likewise, Bottez employs the semantic strategy of distribution change in order to make the imagery more vivid ("de braţele ce ne încolăceau talia şi ne pipăiau în sala de dans"), whereas the second translation again keeps to the ST structure.

Delving deeper into confronting the translations against the ST, another example is the rendering of the two songs, the first being the anthem "Amazing Grace" or Elvis Presley's brooding "Heartbreak Hotel”. The line "I feel so lonely, baby" (48) is rendered as "Mă simt atât de singur, iubito" (Paladin, 74) and as "Mă simt atât de singur, puico" (Leda, 57). As such, the choice of the noun 'puică' which, popularly, is a term of endearment used to refer to a loved one, is more old-fashioned than "iubito", the generally-preferred choice. However, considering the fact that Elvis' song was popular in the 1950s, this 'old-fashioned' choice is certainly fitting for the context.

Some differences are more subtle in nature, hinting at the jabs that the author takes at the phallogocentric perspective and the ever-present male gaze, but also at her playful style and allusions. As such, it is interesting to note that, while Bottez incorporates the idea of handmaids seen as mere possessions, as cattle to be poked, prodded and impregnated against their will, Marin-Caea prefers to resort to some kind of attenuation in expressing this meaning:

ST: He stops at the foot, his fingers encircling the ankle, briefly, like a bracelet, where the tattoo is, a Braille he can read, a cattle brand. It means ownership. (209)

TT1 (Bottez): Se opreşte la picior, înconjurându-mi gleznele, ca o brăţară, acolo unde e tatuajul ca o inscripție în Braille pe care o poate citi, ca o vită înfierată cu emblema proprietarului. (261)

TT2 (Marin-Caea): Se oprește deasupra labei piciorului, cuprinzându-mi glezna cu degetele strânse ca o brățară peste locul unde am tatuajul, o inscripție în Braille pe care el n-o poate citi, ca la un animal însemnat cu fierul înroșit. Semnul proprietății. (332) [all emphases mine]

Bottez resorts to the Syntactic strategy of cohesion change, opting for a sentence that flows, rather than using a fullstop as in the ST; the second version retains the ST structure. However, Marin-Caea's translation mistranslates the part where the Commander can read the tattoo, the mark of the handmaids, as she renders it exactly the other way around, thus misleading the reader. In this case, this cannot be construed as a colossal mistake, but such misses and 
mistranslations can add up and paint a slightly different picture in the mind of the target readers, which may differ to varying degrees from what the author intended. The fact that Monica Bottez was aware of the implication is apparent in the Endnotes she wrote with respect to her translation: "The idea of possession is emphasized by the tattoo on the handmaids' ankles, who are then treated as a herd of cattle" (Bottez' Translator Gloss at the end of the translation 426 -427, my translation).

Another 'deviation' would be in the same chapter, namely 39, where Offred describes Fred as "[...] not an unkind man; that, in other circumstances, I even like him.” (p. 209), the implication here being that she does not dislike him, he is bearable at times, without there being any hint of a romantic crush. The 2006 translation renders this more accurately ("Îmi spun că nu e un om rău; că, înalteîmprejurări, mi-e chiar simpatic.” 261), as opposed to the 2017 version, where a romantic interest is implied ("[...] în alte împrejurări, chiar îmi place de el." 332).

The 1995 and 2006 version seems to flow more naturally, it is defined by a greater degree of 'literariness' (it could be referred to as livresque, as French scholars sometimes call this elusive quality):

ST: He's down to the shirt; then, under it, sadly, a little belly.

TT1 (Bottez): E în cămaşă, iar dedesubt, trista priveliște a unei burţi nu prea mari.

TT2 (Marin-Caea): E în cămașă; iar dedesubt, din păcate, are ceva burtă.

In this particular instance, Marin-Caea's version seems to draw closer to a more modern reader, employing a less formal language and style and using the pragmatic strategy of interpersonal change (toward a more casual tone). Furthermore, there is a slight mistranslation in the Leda version, as Bottez contradicts herself: in the source text, Offred's description implies that Waterford's looks were not desirable, whereas, in Romanian, the implication is that it would have been better if his belly had been bigger.

As far as the translators' individual style is concerned, as Mona Baker points out in her 2000 article "Towards a Methodology for Investigating the Style of a Literary Translator", translation has always been regarded as 'derivative', thus "[...] a translator cannot have, indeed should not have, a style of his or her own, the translator's task being simply to reproduce as closely as possible the style of the original.” (244). Scholars such as Theo Hermans, Rachel May or Christina Gullin have also focused on the traces left behind by the translator (the eternal visibility/invisibility dilemma). In the case at hand, the 
most glaring traces are the paratextual elements, namely the footnotes added by the two translators, with the mention that Monica Bottez also has an Endnotes section (glosses). Quantitatively speaking, the 2017 version makes use of 60 footnotes, whereas the 2006 (and 1995) version has 53. Explanatory footnotes thus prevail in the Paladin version, some more felicitous than others; as such, while some are quite welcome additions for readers ${ }^{1}$ (i.e. p. 30 "In English, the preposition is indicative of possession; thus, the name Ofglen can be rendered as 'A lui Glen'. In fact, all Handmaids receive such a name, based on the first name of the Commander to whom they have been assigned." ${ }^{2}$ ), others are quite unnecessary, as in the Tupperware rendition below.

Referring strictly to the translators' creativity and capacity to be playful and toy with language the way Atwood does, Bottez' translation certainly shows her experience in the literary realm.

ST: I'm giving an underwhore party. [...] You know, like Tupperware, only with underwear. (49)

TT1 (Bottez): Dau o petrecere de univcurve. Ştii tu. Numai în lenjerie de corp deocheată. (59)

TT2 (Marin-Caea): Dau o petrecere cu lenjerie sexoasă. [...] Stii tu, ca la prezentările Tupperware, dar cu lenjerie de corp.(76) [all emphases mine]

Working in a target-oriented direction, Bottez keeps the university reference, while eliminating the culture-specific item (Tupperware) as Moira talks about being in college (university) and throwing a party. In the source text, the humor comes from the homophony 'Tupperware-underwear', while also bearing the feminist implication behind Tupperware parties, where women would invite neighbors over to buy products (similar to Avon traveling ladies). Thus, an allusion is made to housewives in the 1950s and '60s, confined to certain roles (mothers, wives, cleaners). The cultural reference is more difficult to grasp in Romanian, as most readers are not familiar with this notion. The gap between [Romanian and American/Canadian] cultures is such that the reference does not quite allow for the same effect. Marin-Caea's 2017 source-oriented version keeps the Tupperware reference; in resorting to an explanatory footnote, she uses the pragmatic strategy of visibility change, making her translatorial

\footnotetext{
${ }^{1}$ No such footnote is present in the Leda and Univers versions. However, it must be said that the translator, Monica Bottez, explains the names and their meaning in her Endnotes (p. 426-427). As such, the diligent readers who also take the time to read the translator's explanations will be more than enlightened in this respect.

${ }^{2}$ My translation of Diana Marin-Caea's footnote on p. 30.
} 
presence known in the text. However, as such, she needs to explain it to the readers, hence the presence of a footnote on page 76: "A party where the host gives guests the chance to buy Tupperware dishware, thus receiving a commission from the company" [my translation].

The analyst imparts no judgment here, as some translators may choose to respond to the author's ludic nature and reciprocate in kind, whereas others prefer to make use of footnotes and both kinds of attitudes and ensuing translation strategies have their pros and cons.

Another example of the translators' reactions to Atwood's on the nose word play and preference for puns carrying profound meanings is apparent in the following excerpt:

ST: In front of us, to the right, is the store where we order dresses. Some people call them habits, a good word for them. Habits are hard to break. (26)

TT1 (Bottez): În faţa noastră, pe dreapta, e magazinul unde ne comandăm rochiile. Unii le numesc robe $^{5}$ şi e bine zis, căci roba te robește $^{6}$. [Endnote 5: Habit - 1) costum, veşmânt caracteristic unei profesiuni, rang sau funcţie; 2) obicei.) Endnote 6: Joc de cuvinte greu de tradus: habits are hard to break. Sintagma înseamnă, pe de o parte "obiceiurile sunt greu de schimbat". Dar verbul break, prin asociere cu expresia to break loose (a scăpa, a se elibera, a fugi), sugerează forța de constrângere a uniformei de castă specifică societăţii din Galaad.] (36 Leda, 28 Univers)

TT2 (Marin-Caea) : În față, pe dreapta, e magazinul unde ne comandăm hainele. Unii le numesc straie, iar ăsta mi se pare un cuvânt bun, care te duce cu gândul la ceva greu de schimbat și constrângător totodată. (37 Paladin) [all emphases mine]

In the 2006 and 1995 translations, Bottez resorts to the semantic strategy of paraphrase, opting for a similar pun, which entails the deeper meaning of service against one's will. According to the Romanian DEX, 'a robi' means taking away someone's freedom, holding them captive, keeping a person in servitude from a political, economic and social standpoint, exploiting them. Meanwhile, 'roba' refers to a ceremonial robe, which is fitting in the context, because that is exactly what the Handmaids' red flowing robes were: beacons signaling what they represented from afar. The pragmatic strategy of visibility change is employed in the Leda and Univers versions, and not in the Paladin translation, as Bottez explains in her footnote that the pun is hard to render into Romanian so as to convey exactly the same meaning and effect; moreover, by 
means of the pragmatic strategy of explicitness change, she further explains what the verb 'break' entails, in reference to 'breaking loose', escaping the shackles put on these women through their red uniforms. This is a telling example of Atwood's writings carrying profound ideological implications and requiring a reader who is willing to decipher meanings, or at least open to learning more and becoming initiated in this respect. In such cases, the translator bears the responsibility of making these elements (experimental writing, sharp and satiric, ludic in the way it flouts norms and plays with meanings and words) more accessible to target readers who not only cannot grasp them due to the language barrier, but also because of their lack of knowledge in ongoing American/western ideologies, particularly in the 1990'sand beginning of the years 2000. As such, the Univers and Leda version manages to stay true both to the author's voice and style, while also bringing Atwood closer to the Romanian readers. In the Paladin version there is no explanatory footnote, but the pun is lost in translation, as the translator resorts to the semantic strategy of distribution change and to the pragmatic strategy of explicitness change, attempting to explain the expression 'habits are hard to break' ("te duce cu gândul la ceva greu de schimbat și constrângător totodată"); the readers will understand the gist, but the word play is gone, so are the deeper ideological implications.

In the following excerpt, neither translator seems to have fully grasped the wordplay or managed to render it faithfully:

ST: As long as I lie still. The difference between lie and lay. Lay is always passive. Even men used to say, I'd like to get laid. Though sometimes they said, I'd like to lay her. All this is pure speculation. I don't really know what men used to say. I had only their words for it. (35)

TT1 (Bottez): Câtă vreme zac întinsă fără să mă clintesc. Diferența dintre a zăcea şi a pune. A pune e totdeauna pasiv. Chiar şi bărbaţii spuneau pe vremuri mi-ar plăcea să fiu pus la pământ. Ba parcă uneori spuneau mi-ar plăcea să o pun jos. De fapt, asta-i pură speculaţie. Nu ştiu cu adevărat ce spuneau, știu numai din mărturisirile lor. (Leda 51, Univers 38)

TT2 (Marin-Caea): Atâta vreme cât stau nemișcată. Diferența dintre „, face" și "a sta". Statul e întotdeauna pasiv. Până și bărbații spuneau odinioară „Mi-ar plăcea să stau cu tipa aia”. Deși uneori spuneau și „Miar plăcea să-i fac felul ăleia”. Toate astea sunt pure speculații. Nu prea știu cu adevărat ce spuneau bărbații, știu doar ce povesteau ei despre asta. [all emphases mine] 
In the Leda and Univers version, the misogynistic allusion is lost in translation, as 'to get laid' refers to men having intercourse with women (it is a crass expression, carrying a demeaning implication). Granted, it is difficult in the case of such a gap between an analytic language like English and a fusional one, like Romanian (not as concise as the former), to reconcile both the wordplay, as well as the derogatory expression in this particular instance. As such, the 2006 version loses the reference to the objectification of women, whereas the 2017 version manages to render it to a wider extent, with the notable exception of "să-i fac felul ăleia", which resorts to the pragmatic strategy of interpersonal change, altering the degree of formality; however, the meaning is distorted, as 'a-i face felul cuiva' does not refer to sexual intercourse, but to killing a person (or at least harming them). In this excerpt, there are mistranslations and distortions in both Romanian versions, and they fail to accurately render the wordplay.

Lastly, embarking 'in search of the translator(s)', Professor Monica Bottez teaches at the University of Bucharest, in the English Department, and it is important to mention that she also has a close connection to Canadian literature, as she introduced it on the MA Canadian Studies curriculum; besides, she has been a Canadianist for over 20 years. Her publications include the 2004 Infinite Horizons: Canadian Fiction in English, Bucharest University Press, as well as a 2012 article published in the University of Bucharest Review, "Another Penelope: Margaret Atwood's The Penelopiad”, 2017's “The Symbolism of Rebirth in Margaret Atwood's Surfacing” and many more, not forgetting, of course, her translation (both the 1995 version and the 2006 revised edition) of The Handmaid's Tale, as well as a translation of David Mamet's Theatre (Teatrul, Curtea Veche Publishing 2013) and David Malouf's 1978 novel An Imaginary Life ( $O$ viață imaginară. Roman despre Ovidiu, epublishers, Coresi, 2019). As such, with respect to her background, it is safe to say that she is an experienced translator, and has the necessary literary and cultural knowledge needed for grasping the subtleties and deeper meanings. Furthermore, as proven by looking at her resumé and publications, she has written multiple articles and papers on Atwood's novels and symbolism, therefore she is also familiar with the author's style and proclivity toward certain themes, tropes and wordplay.

With respect to the translator of the 2017 version, Diana Marin-Caea, she is also a translator, though based on the titles she has translated, she specializes in children's literature (her translations for Arthur Publishing include Judy Blume's Tales of a Fourth Grade Nothing / Povestea unui omuleț din clasa a IV-a, Superfudge / Supercolțunaș, which came out in 2019 and 2021, David Edward Walliams' Gangsta Granny / Mătușica îngrozitoare, Billionaire Boy / Băiatul miliardar, 2021). It is important to note that she also translated another 
Atwood novel the same year as her Handmaid translation, 2009's The Year of the Flood (Anul potopului, ART Publishers, 2017), and she has written a series of educational children's books as well (Communication in Romanian - The Great Travels of the OAC Toadie in Alphabet Land, ART Klett Publishing, 2013, 2018) (Cartepedia).

All in all, all three (or rather two) versions have their unique translation solutions, with the translators resorting to visibility change more often than not, in their attempts to clarify meaning. However, in so doing, Monica Bottez is better equipped, through her academic background, and knowledge of Canadian/Western feminist ideologies, to translate in a "target-oriented" direction, while staying true to Atwood's playful and ironic style and preference for puns, as well as to her feminist overtones. Moreover, the 1995 (and 2006) version also has a gloss/Endnotes section at the end, where the translator explains several aspects related to the novel, both language and content-wise, with the aim of enlightening the readers and making them more familiar with the themes, tropes and symbolism in the novel. The 2017 Paladin version lacks the latter element, and feels less 'daring' with respect to the translation solutions employed, as the translator opts for literal translation in most cases, staying close to the source text, and resorting to footnotes where she deems that ST meanings are too opaque.

\section{Works Cited}

\section{Primary sources}

Atwood, Margaret. The Handmaid's Tale. Thorndike Press Large Print, 2017.

--- Povestea slujitoarei. Translated by Diana Marin-Caea, Paladin.2017.

--- Galaad 2195 (The Handmaid's Tale). Translated by Monica Bottez, Univers, 1995

--- Povestea cameristei. Translated by Monica Bottez, Leda, 2006.

\section{Secondary Sources}

Berman, Antoine. Toward a Translation Criticism: John Donne, trans. Françoise Massardier-Kenney, The Kent State University Press. Kent. Ohio, 2009.

Baker, Mona. "Towards a Methodology for Investigating the Style of a Literary Translator.” Target 12:2, 2000, pp. 241-266 .

Boase-Beier, Jean, Lina Fisher and Hiroko Furukawa, editors. The Palgrave Handbook of Literary Translation. Palgrave Handbooks Macmillan, 2018.

Biblia sau Sfânta Scriptură, Editura Institutului Biblic și de misiune al Bisericii Ortodoxe Române București, 1988.

Chesterman, Andrew. Memes of Translation: The Spread of Ideas in Translation Theory. Amsterdam: J. Benjamins, 1997. 
Davies, Madeleine. “Margaret Atwood's female bodies.” The Cambridge Companion to Margaret Atwood, edited by Coral Ann Howells, Cambridge University Press, 2006, pp. 58-72.

Devaul, Anna. “A Great Darkness Filled with Echoes” in A Womb of One's Own The Handmaid's Tale and Philosophy, edited by Rachel Robison-Greene, Open Court Publishing Company, 2019.

Kaminski, Margaret. "Preserving Mythologies." Margaret Atwood: Conversations. Ed. Earl G. Ingersoll. Princeton: Ontario Review P, 1990, pp. 27-32.

Macpherson Slettedahl, Heidi. The Cambridge Introduction to Margaret Atwood, Cambridge University Press, 2010.

Matthews, Aisha. "Gender, Ontology, and the Power of the Patriarchy: A Postmodern Feminist Analysis” Women’s Studies, 2018.

Miroiu, Mihaela. "Experiențele femeilor și pericolul feminist." Femei și feminisme, Secolul XX, edited by Ștefan Augustin Doinaș, 7-9, 1996, pp. 21-36.

Tolan, Fiona. Margaret Atwood Feminism and Fiction. Rodopi, 2007.

\section{Electronic sources}

Bauer, Patricia , Curtis, Abi and Lowne, Cathy. "The Handmaid's Tale". Encyclopedia Britannica, 18 Sep. 2019, https://www.britannica.com/topic/The-HandmaidsTale-by-Atwood. Accessed 18 August 2021.

Britannica, The Editors of Encyclopaedia. "Margaret Atwood". Encyclopedia Britannica, 7 Jan. 2021, https://www.britannica.com/biography/MargaretAtwood. Accessed 17 August 2021.

"Monica Bottez." British Cultural Studies University of Bucharest, Wordpress.com, https://bcsunibuc.wordpress.com/about/teaching-staff/monica-bottez/ Date accessed 27Aug. 2021.

“Monica Botez”. Google Academic, https://scholar.google.ro/citations?hl=ro\&user=P8XzzpEAAAAJ\&view_op=list _works\&gmla=AJsN-

F4U_aONgM30kvUTQ9wnISDCbaJDwaEhUzUctMvoTKRmwOyvq5Mds5G Pq8pQS3qEY7ooGRe7zxfERdxxFOHBwB27mYaEOYm2TiwfuGCJM39VRU R-sJoi7qV6-gM-bc2ICBvcLGDrVFa9Ic3ajKSg_N0WzBFVWw Date accessed 10 Aug. 2021.

"Diana Marin Caea.” Cartepedia, https://www.cartepedia.ro/autor/diana-marin-caea15923. Date accessed 27 Aug. 2021.

\section{BIONOTE}

Alexandra VRÎNCEANU is a translator and interpreter, specializing in both literary translations and EU texts and technical translations. She is currently a $\mathrm{PhD}$ student at Alexandru Ioan Cuza University of Iasi, working on a paper that aims to take a more in-depth look at feminist ideology in translated literature. Moreover, she 
also teaches practical courses (translation, listening and grammar) for 1st and 2nd year students at the Faculty of Letters.

E-mail: alexandra.vrinceanu94@gmail.com 